\title{
Belowground Carbon and Nitrogen on a Thinned and Un-Thinned Seasonally Dry Tropical Forest
}

\author{
Deodato do Nascimento Aquino ${ }^{1}$, Eunice Maia de Andrade ${ }^{2 *}$, \\ Andréa Dardes de Almeida Castanho3 ${ }^{3}$, Lécio Resende Pereira Júnior², \\ Helba Araújo de Queiroz Palácio4 \\ ${ }^{1}$ Instituto Nacional de Colonização e Reforma Agrária, Fortaleza, Brazil \\ ${ }^{2}$ Department of Agricultural Engineering, Federal University of Ceará, Fortaleza, Brazil \\ ${ }^{3}$ Woods Hole Research Center, Falmouth, USA \\ ${ }^{4}$ Federal Institute of Education, Science and Technology, Iguatu, Brazil \\ Email: *eandrade.ufc.@gmail.com
}

How to cite this paper: do Nascimento Aquino, D., de Andrade, E.M., de Almeida Castanho, A.D., Júnior, L.R.P. and de Queiroz Palácio, H.A. (2017) Belowground Carbon and Nitrogen on a Thinned and UnThinned Seasonally Dry Tropical Forest. American Journal of Plant Sciences, 8, 20832100.

https://doi.org/10.4236/ajps.2017.89140

Received: July 14, 2017

Accepted: August 5, 2017

Published: August 8, 2017

Copyright (C) 2017 by authors and Scientific Research Publishing Inc. This work is licensed under the Creative Commons Attribution International License (CC BY 4.0).

http://creativecommons.org/licenses/by/4.0/

\begin{abstract}
The aim of this study was to quantify the dynamics of herbaceous biomass and fine root productivity, and their relationship to stocks of carbon and nitrogen, in the Vertisols of two adjacent watersheds of a seasonally dry tropical forest (SDTF) under two different types of ground cover. The two watersheds are located in the county of Iguatu in the State of Ceará, Brazil. The control watershed of $2.1 \mathrm{ha}$, has been under regeneration for 35 years $\left(\mathrm{RC}_{35}\right)$, while the second watershed ( $1.1 \mathrm{ha}$ ) was subjected to thinning for a period of 5 years $\left(\mathrm{TC}_{5}\right)$. The sampled variables were herbaceous shoot biomass, fine roots, gravimetric moisture, the isotope $\delta^{13} \mathrm{C}(\%)$, total soil carbon (TSC) and total nitrogen (TN) in the $0-20,20-40$ and $40-60 \mathrm{~cm}$ layers, between April 2013 and March 2014. To quantify herbaceous shoot biomass, samples were taken monthly. For TSC and TN, the campaigns were held every two months. The data underwent analysis of means and were compared by $t$-test $(p<0.05)$. Under $\mathrm{TC}_{5}$, there was an increase in the stocks of TSC and TN of 151 and $137 \%$ respectively in the $40-60 \mathrm{~cm}$ layer, in relation to $\mathrm{RC}_{35}$. The implementation of thinning in a SDFT is seen as a management alternative to be considered in sustainability programs in the semi-arid region, contributing to maximising the production of herbaceous forage for feeding large and small ruminants, and for bee pasture, in addition to increasing the stock of carbon in the soil of SDFT and reducing global warming.
\end{abstract}

\section{Keywords}

Carbon Sequestration, Dry Forests, Isotope $\delta^{13} \mathrm{C}$, Herbaceous Plants 


\section{Introduction}

In the last few decades the scientific community has turned to the study of carbon stocks in many different compartments of tropical forests [1] [2] [3], due to their being an important component of terrestrial carbon. However, the same cannot be said about seasonally dry tropical forest (SDTF) [4] [5] [6], which cover an area of approximately $105.104 \mathrm{~km}^{2}$. Of this total, $54.2 \%$ are distributed over two large areas in South America [7], with the most extensive, known as the Caatinga, in the northeast of Brazil. Over the centuries, the primary use of these forests has been for agriculture, timber and animal pasture [8]. The production of any of these components requires the practice of thinning in different degrees. The selective removal of trees and shrubs through thinning is used in order to improve the process of colonisation, reducing the competition for water, light and nutrients, and opening up space for the growth of small herbaceous species [9] [10]. The increased availability of herbaceous plants in SDFT has therefore been achieved through changes in the structure and architecture of the tree and shrub vegetation [11] [12].

Early studies of thinning in SDFT were intended to identify managements which would give greater productivity of fibre and biomass [13]. Studies show that thinning promotes the emergence of an herbaceous layer [14], enables water content in the soil [15] [16] [17] and can add biomass to the soil [18] [19]. However, there is little research that focuses on the significance of thinning on root biomass in the soil of a SDFT [4] [6]. Further, it should be noted that the SDFT located in the northeast of Brazil (approximately $900,000 \mathrm{~km}^{2}$ ) has been little investigated as to the dynamics of fine roots or shoot biomass [5] [20] [21]. Although thinning is a very common practice in the region, there is still no research into the effect of thinning on the stock of carbon and nitrogen in the soil.

To monitor the quality of the soil, so that changes in the management systems adopted by farmers may be suggested in time to prevent degradation of the dry region [22], it is necessary to define environmental attributes that can be easily measured [23]. In this respect, determination of the total soil carbon (TSC) and total nitrogen (TN) can unanimously be found in the literature as key indicators of soil quality [24] [25], both in agricultural systems and areas of native vegetation [26] [27]. It is believed that the stock of TSC and TN in the soil of a fragment of a SDFT subjected to thinning is lower than under regeneration for 35 years of ecological succession. Given the above, the aim of this study was to quantify the dynamics of herbaceous biomass and fine-root productivity, and their relationship to changes in the stock of TSC and TN in the soil of a SDFT under two different types of land use in the northeast of Brazil.

\section{Materials and Methods}

The semi-arid region of northeastern Brazil is characterised by high population density, comprising approximately 27 million people in an area of $982,563 \mathrm{~km}^{2}$. Different types of vegetation develop in the region, predominantly caatinga, a 
type of seasonally dry tropical forests (SDTF), with an area of $844,453 \mathrm{~km}^{2}$.

\subsection{Experimental Area}

The study was carried out in two watersheds $\left(6^{\circ} 23^{\prime} 44^{\prime \prime} \mathrm{S} ; 39^{\circ} 15^{\prime} 24^{\prime \prime} \mathrm{W}\right)$, in county of Iguatu in the State of Ceará, Brazil (Figure 1). The watersheds are adjacent and under different types of land use, $\mathrm{RC}_{35}$ (SDFT under regeneration for 35 years) and $\mathrm{TC}_{5}$ (SDFT under thinning for 5 years), with an area of 2.1 and 1.1 ha, and an average slope of $10.6 \%$ and $8.7 \%$ respectively. Both have a second-order drainage course and ephemeral water regime.

The vegetation in the study area is mostly made up of hyperxerophilic seasonally dry tropical forests (SDTF) (steppe-like savannah), deciduous, with a large variety of thorny species in secondary ecological succession. The following species predominate in the area: Aspidosperma pyrifolium, Commiphora leptophloeos (Mart.) J. B. Gillett, and Mimosa caesalpiniaefolia Benth, (Combretum leprosum and Piptadenia stipulacea). The predominant vegetation unit is a medium SDTF, with arboreal layers of variable density, and individuals with an average height of from 7 to $15 \mathrm{~m}$. The climate in the region is hot semi-arid, with an aridity index of 0.44 , i.e. semi-arid. The region is also characterised by high potential evaporation $\left(1988 \mathrm{~mm} \cdot \mathrm{year}^{-1}\right)$, with higher values during the seven months of less rainfall (June to December). The average historical rainfall for the town of Iguatu is $864 \pm 304 \mathrm{~mm}$ (average for 1932-2013). Temporal distribution of the rainfall shows $85 \%$ to be concentrated from January to May, of which around 30\% is recorded in March. Average annual temperature for the region is $27^{\circ} \mathrm{C}$.

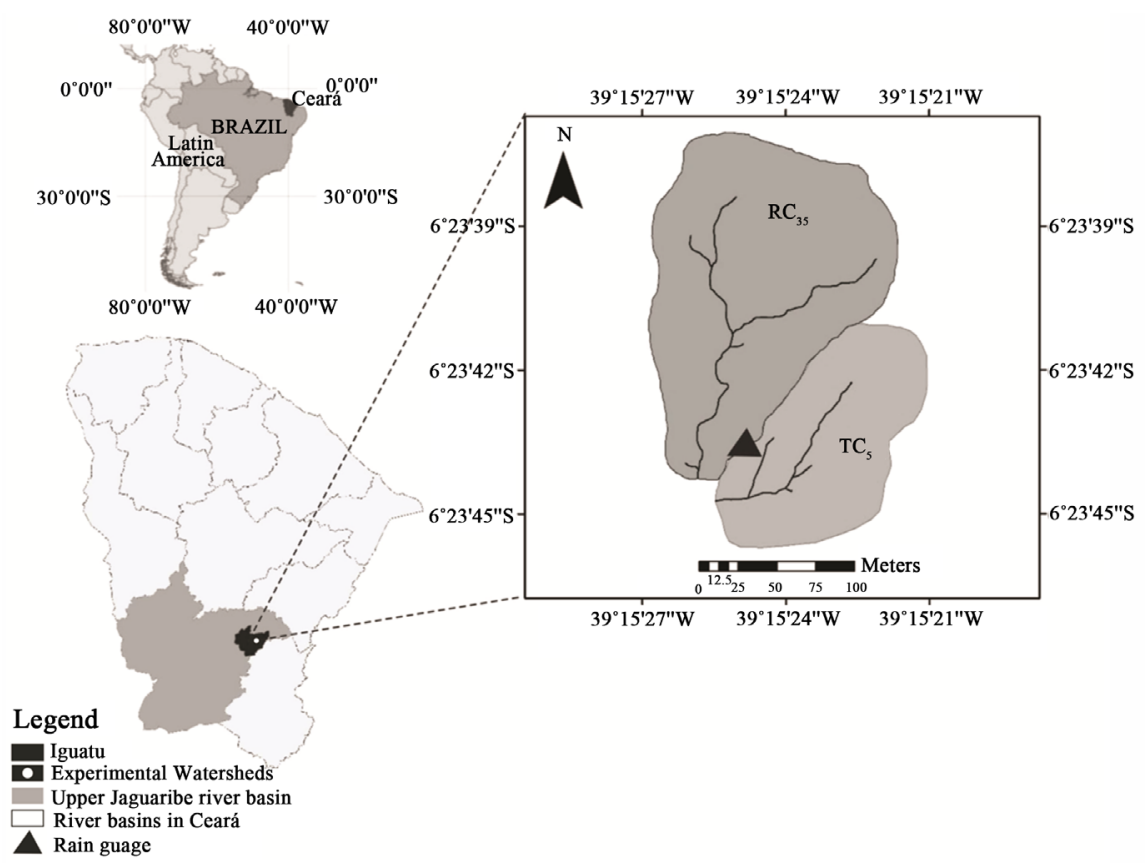

Figure 1. Location of the experimental watersheds showing the management of SDFT under regeneration $\left(\mathrm{RC}_{35}\right)$ and thinning $\left(\mathrm{TC}_{5}\right)$. 


\subsubsection{History of Land Occupation}

With relation to the history of land occupation, before 1980 the areas of both experimental watersheds were used for the cultivation of subsistence species, specifically maize (Zea mays L.) and cotton (Gossypium L), and have been maintained in various stages of recovery and succession since that time. The $\mathrm{RC}_{35}$ management represents natural vegetation under regeneration for about 35 years, while $\mathrm{TC}_{5}$ was submitted to thinning in December of 2008, 2010 and 2012. Thinning consisted of removing those plants where the diameter of the stem was less than $0.10 \mathrm{~m}$ at breast height, while herbaceous-sized plants and the organic residue of the thin branches from thinning were left in place. It should be noted that throughout the experiment there was no grazing in either of the experimental watershed. To determine the variables being investigated, fifty $10 \times 10 \mathrm{~m}$ sample units were distributed across the main course in both watersheds, $\mathrm{RC}_{35}$ and $\mathrm{TC}_{5}$, marked out and identified in loco with metal plates according to [28] methodology.

\subsubsection{Rainfall}

Rainfall data were measured on 5-min intervals in an automatic weather station, from which rainfall depth $(\mathrm{P})$ was obtained. Of the total rainfall, $61 \%$ was recorded over three months, expressing high temporal variability, with a dry period or a period of low rainfall between July and December (Figure 2). The rainfalls were concentrated from April to Jun 2013 and from January to March 2014, while the period from August to December was characterized as dry. Any month with a rainfall below $50 \mathrm{~mm}$ was considered to be dry [29]. Information on soil temperature in both areas was recorded every 4 hours at a depth of $10 \mathrm{~cm}$, employing Hobo Pendant ${ }^{\circledR}$ model 64K-UA-002-64 Temperature/Light sensors. The

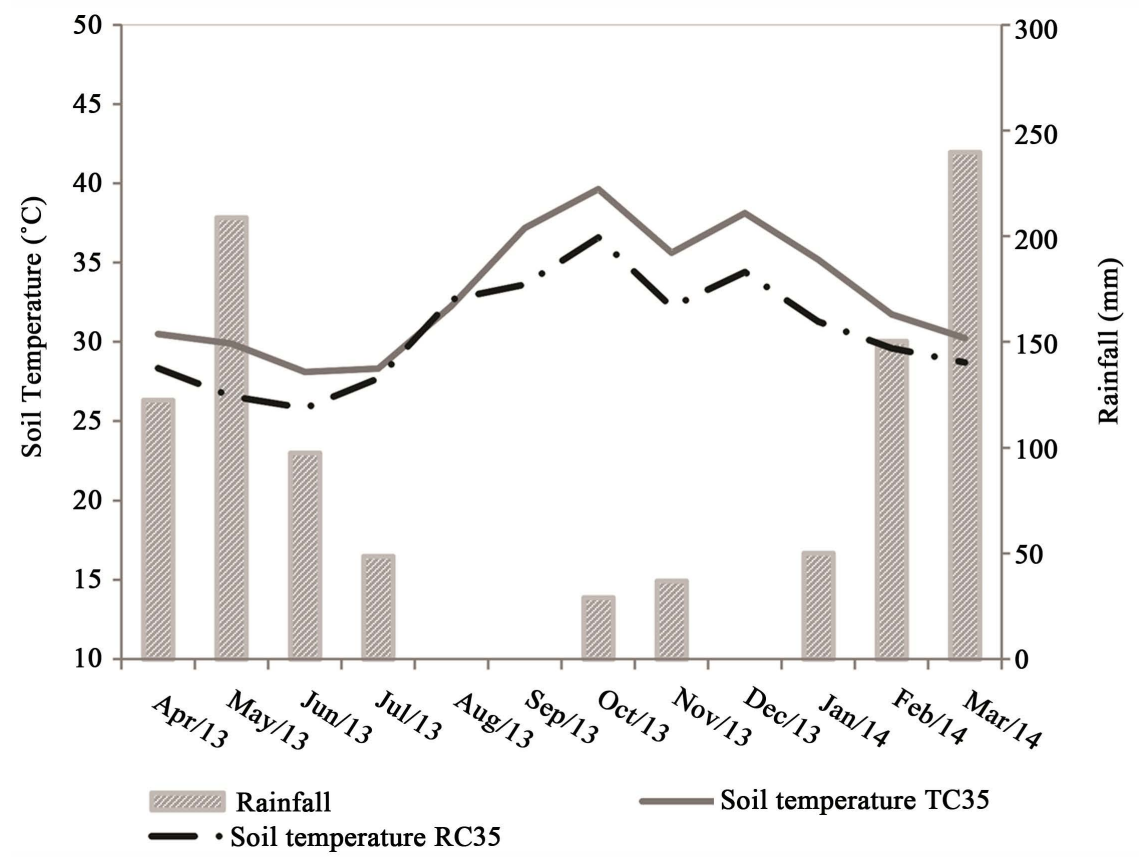

Figure 2. Rainfall $(\mathrm{mm})$ and the mean monthly temperature $\left({ }^{\circ} \mathrm{C}\right)$ of the soil $(10 \mathrm{~cm})$. 
highest soil temperatures in the $10 \mathrm{~cm}$ layer coincided with the dry period, reaching an average in October of $40^{\circ} \mathrm{C}$ and $36.6^{\circ} \mathrm{C}$ in $\mathrm{TC}_{5}$ and $\mathrm{RC}_{35}$ respectively.

\subsubsection{Soil Characteristics}

The soil of both areas was classified as a Vertisol, with a predominance of group 2:1 expansive clay minerals, particularly montmorillonite. As regards the physicochemical properties of the soil, it can be seen that both managements had soils of similar characteristics (Table 1). The $\mathrm{pH}$ tends towards neutral, ranging between 6.7 and 6.9, and the texture is silty loam, with the exception of the $0-20$ $\mathrm{cm}$ layer present in TC5. The soil density of the soil showed little variation, the highest values being recorded in the $40-60 \mathrm{~cm}$ layer of $\mathrm{RC}_{35}$, with values of 1.50 $\mathrm{g} \cdot \mathrm{cm}^{-3}$.

\subsection{Herbaceous Biomass}

Sampling to quantify the production of herbaceous shoot biomass was carried out monthly, with 10 replications for each management $\left(\mathrm{RC}_{35}\right.$ and $\left.\mathrm{TC}_{5}\right)$ from April 2013 to March 2014, following the methodology presented by [28]. The herbaceous material from the ten sampling units was weighed and shredded while still fresh, and then reduced to an aliquot of $500 \mathrm{~g} / \mathrm{sample}$ unit. To get the air-dry weight, samples were dried in a forced air circulation oven at $60^{\circ} \mathrm{C}$ $70^{\circ} \mathrm{C}$ and weighed on an analytical balance with a precision of $0.01 \mathrm{~g}$.

\subsection{Fine roots Biomass}

To determine fine-root biomass ( $\phi<2 \mathrm{~mm}$ ), the methodology proposed by [30] was followed. To extract the fine roots, a hollow cylindrical aluminum probe with an internal diameter of $4.5 \mathrm{~cm}$ was used. The samples were taken from the $0-10,10-20$ and $20-30 \mathrm{~cm}$ layers in June (rainy season) and November (dry season), in five randomly selected sampling units for each management.

\subsection{Soil Moisture, Total Soil Carbon and Total Nitrogen}

To quantify the levels of soil moisture, total soil carbon (TSC) and total nitrogen

Table 1. Soil density, $\mathrm{pH}$ and particle size characteristics in managements of regenerating $\left(\mathrm{RC}_{35}\right)$ and thinned $\left(\mathrm{CR}_{5}\right)$ SDFT.

\begin{tabular}{ccccccccc}
\hline \multirow{2}{*}{ Management } & $\begin{array}{c}\text { Depth } \\
(\mathrm{cm})\end{array}$ & $\mathrm{pH}$ & $\begin{array}{c}\text { Moisture } \\
(\%)\end{array}$ & $\begin{array}{c}\text { Density } \\
\left(\mathrm{g} \cdot \mathrm{cm}^{-3}\right)\end{array}$ & Sand & Clay & Loam & Textural Class \\
\cline { 8 - 9 } & $0-20$ & 6.9 & 16.24 & 1.31 & 7.50 & 68.33 & 24.17 & Clay \\
$\mathrm{RC}_{35}$ & $20-40$ & 6.7 & 13.12 & 1.37 & 20.68 & 34.54 & 44.78 & Clay Loam \\
& $40-60$ & 6.9 & 10.84 & 1.50 & 4.65 & 59.28 & 36.07 & Clay \\
& $0-20$ & 6.7 & 18.84 & 1.36 & 8.44 & 54.91 & 36.65 & Clay \\
& $20-40$ & 6.8 & 17.87 & 1.47 & 9.85 & 63.26 & 26.89 & Clay \\
$\mathrm{TC}_{5}$ & $40-60$ & 6.9 & 16.29 & 1.44 & 4.42 & 60,08 & 35.50 & Clay \\
\hline
\end{tabular}


(TN) in the soil, collections were made every two months, from April 2013 to March 2014, in the 0 - 20, 20 - 40 and $40-60 \mathrm{~cm}$ layers of five randomly selected sampling units for each management. The soil collected from each layer was then homogenised into compound samples and sent for further laboratory analysis. TSC was determined with the aid of a Total Organic Carbon Analyser, TOC-V, coupled to an SSM-5000A Solid Sample Module. The stock of TSC was calculated following the equation proposed by [31], while TN was determined from an expression adopted by [32].

$$
\text { TSC or TN }=\frac{(\text { Tc or } T n) \times D s \times e}{10}
$$

where TSC or TN is the carbon or nitrogen stock $\left(\mathrm{Mg} \cdot \mathrm{ha}^{-1}\right)$; Tc or $T n$ is the measured total organic carbon or total nitrogen in the sampled soil layer $\left(\mathrm{g} \cdot \mathrm{kg}^{-1}\right) ; D s$ is soil bulk density in the sampled soil layer $\left(\mathrm{g} \cdot \mathrm{cm}^{-3}\right) ; e$ is the depth of the soil layer $(\mathrm{cm})$.

\subsection{Carbon Isotopes $\left(\delta^{13} \mathrm{C}\right)$}

In order to understand the actual contribution of plants with a $\mathrm{C}_{3}$ and $\mathrm{C}_{4}$ metabolism to carbon formation in the two managements being investigated, the stable carbon 13 isotopes $\left(\delta^{13} \mathrm{C}\right)$ were quantified. To do this, soil was collected from ten randomised sampling units at the $0-20,20-40$ and $40-60 \mathrm{~cm}$ layers in each management $\left(\mathrm{RC}_{35}\right.$ and $\left.\mathrm{TC}_{5}\right)$, giving a total of 30 samples for each type of land use. The analyses were carried out by combustion of the samples under a continuous flow of helium in an elemental analyser (Carlo Erba, CHN-1110) coupled to a Thermo Finnigan Delta Plus mass spectrometer. The enrichment or depletion of the ${ }^{13} \mathrm{C}$ isotopic species was measured against a standard, and expressed in "delta permil" [33].

$$
\delta^{13} \mathrm{C}=\left[\left(\frac{R_{\text {amostra }}}{R_{\text {padrao }}}\right)-1\right] \times 10^{3}
$$

where $R$ is the carbon isotope ratio $\left({ }^{13} \mathrm{C} /{ }^{12} \mathrm{C}\right)$ in the sample and in the standard. The standard for carbon is the PDB. Measurement accuracy is $\pm 0.3 \%$.

\subsection{Statistical Analyses}

Mean data for soil temperature, herbaceous shoot dry matter, fine root dry matter, total carbon and total nitrogen, as well as carbon 13 isotope $\left(\delta^{13} \mathrm{C}\right)$, were subjected to an analysis of means test, to find out the effects of sampling months, soil depth and soil moisture, management regimes and their interactive effects on fine root biomass and TSC and TN. Mean differences were considered significant when $p<0.05$ to t-test.

\section{Results}

\subsection{Herbaceous Biomass}

Herbaceous dry biomass (Figure 3) was significantly affected by the manage- 


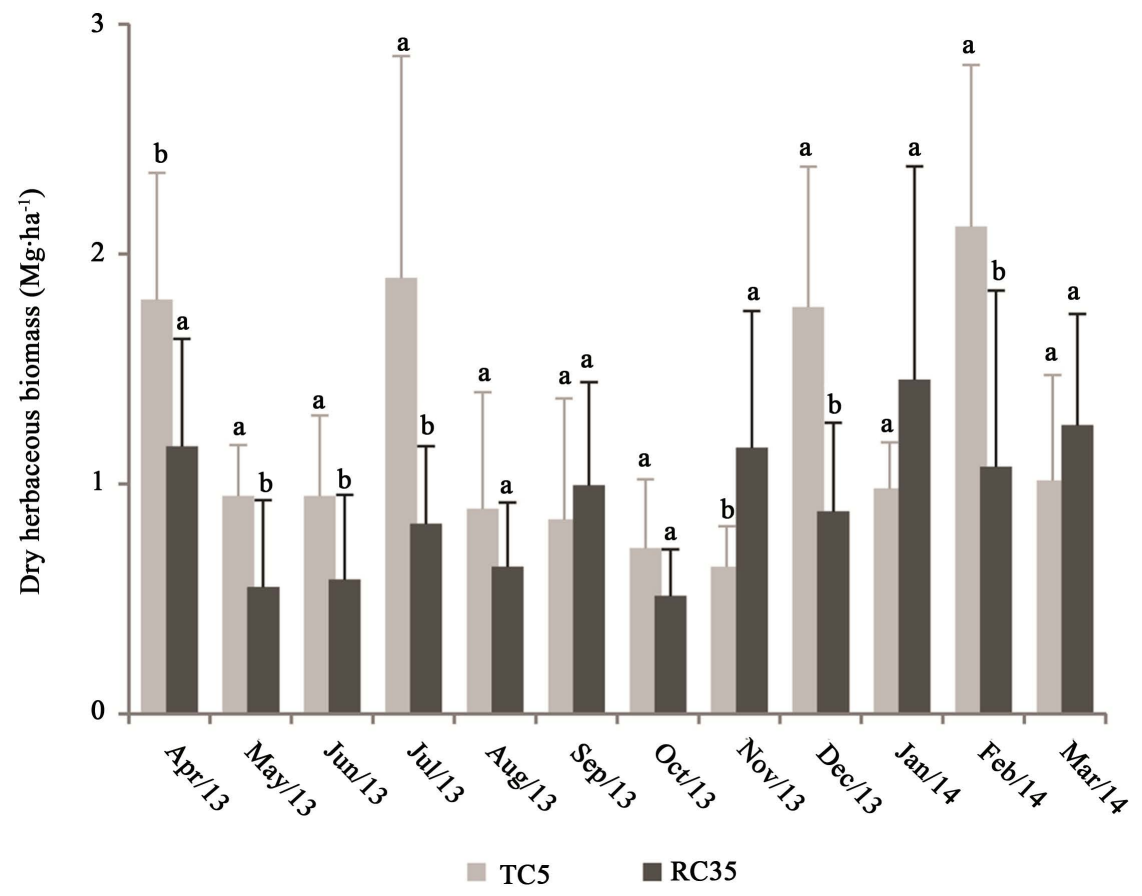

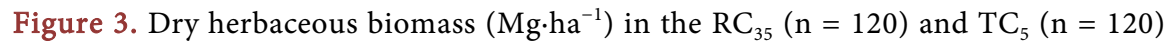
managements. The same letters within each month do not differ statistically by t-test $(p>$ $0.05)$.

ment of the tree and shrub species at a level of $5 \%$ significance. The $\mathrm{TC}_{5}$ area displayed greater productivity for herbaceous dry matter, with an annual mean stock of approximately $1.2 \mathrm{Mg} \cdot \mathrm{ha}^{-1}\left( \pm 0.7 \mathrm{Mg} \cdot \mathrm{ha}^{-1}\right)$ compared with the 0.9 $\mathrm{Mg} \cdot \mathrm{ha}^{-1}\left( \pm 0.5 \mathrm{Mg} \cdot \mathrm{ha}^{-1}\right)$ found in $\mathrm{RC}_{35}$. During the rainy months, from April to July 2013 and February 2014, the production of herbaceous dry biomass in the $\mathrm{TC}_{5}$ was statistically higher than that seen in the $\mathrm{RC}_{35}(p=0.001)$, reaching a peak in February 2014, of approximately $2.3 \mathrm{Mg} \cdot \mathrm{ha}^{-1}$ (Figure 3). However, still with reference to Figure 3, during the dry period (August to November 2013), with the exception of November, no statistical difference was seen $(p>0.05)$ in the stock of dry matter between the managements being investigated. Unlike that seen in $\mathrm{TC}_{5}$, the herbaceous dry matter in $\mathrm{RC}_{35}$ showed few fluctuations (Figure 3), giving a total stock of $1.2 \mathrm{Mg} \cdot \mathrm{ha}^{-1}$ in April 2013, and $1.3 \mathrm{Mg} \cdot \mathrm{ha}^{-1}$ in March 2014.

Although during the rainy period, the stock of herbaceous dry matter in the $\mathrm{TC}_{5}$ was significantly higher $(p \leq 0.05)$ than in the $\mathrm{RC}_{35}$ (Figure 4$)$, during the dry period, no statistical difference was recorded. On the other hand, a comparison between the periods identified that the stock which occurred during the rainy period $\left(1.4 \mathrm{Mg} \cdot \mathrm{ha}^{-1}\right)$ was statistically greater than in the dry period (1.0 $\left.\mathrm{Mg} \cdot \mathrm{ha}^{-1}\right)$. It can therefore be said that the $\mathrm{TC}_{5}$ management expresses a greater sensitivity to the rainfall regime of the region.

\subsection{Fine Root Biomass}

From investigation of the stock of dry fine-root biomass between the dry and 


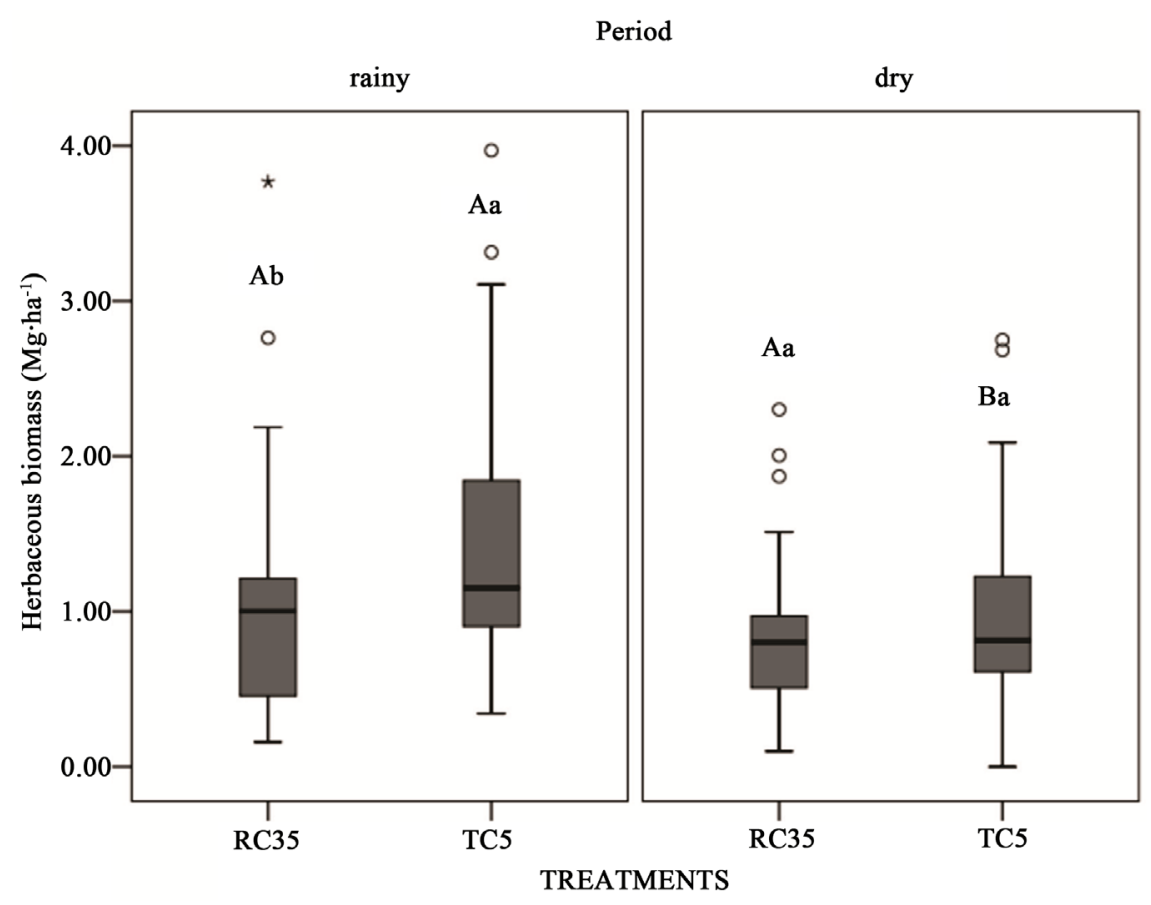

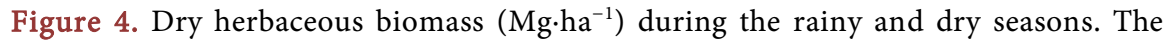
same lowercase letter within a period, and uppercase letter between inter-management period, do not differ statistically by t-test $(p>0.05)$.

rainy seasons, it was identified that in the $\mathrm{RC}_{35}$ only the $20-30 \mathrm{~cm}$ layer (Figure $5(\mathrm{a}))$ did not show a statistical difference $(p=0.530)$.

For the entire layer $(0-30 \mathrm{~cm})$, the stock was $6.5 \mathrm{Mg} \cdot \mathrm{ha}^{-1}$ and $5.6 \mathrm{Mg} \cdot \mathrm{ha}^{-1} \mathrm{re}-$ spectively, with a decrease of only $0.9 \mathrm{Mg} \cdot \mathrm{ha}^{-1}(12.5 \%)$ between the rainy and dry seasons of 2013. The greatest quantities of dry fine-root biomass in $\mathrm{RC}_{35}$ were found during the rainy period in the $0-10 \mathrm{~cm}$ layer $\left(3.5 \mathrm{Mg} \cdot \mathrm{ha}^{-1}\right)$. However, during this period, this layer stored only half the quantity of fine roots found in the $\mathrm{TC}_{5}$ (Figure $5(\mathrm{~b})$ ). The stock of dry fine-root biomass in $\mathrm{TC}_{5}$ during the rainy period showed no significant differences $(p>0.05)$ between layers. Whereas during the dry period, a significant reduction in the stock of fine-root biomass was registered between layers (Figure 5(b)). Summing the stocks of dry fine-root biomass occurring in the three layers gives approximately $21.2 \mathrm{Mg} \cdot \mathrm{ha}^{-1}$ and $14.6 \mathrm{Mg}^{-h^{-1}}$ for the rainy and dry periods respectively. This decrease is equal to a reduction of $6.5 \mathrm{Mg} \cdot \mathrm{ha}^{-1}$ (30.9\%) in only 6 months.

\subsection{Soil Moisture}

Throughout the profile being analysed, the $\mathrm{RC}_{35}$ management displayed values for moisture that were always lower than those quantified in $\mathrm{TC}_{5}$ (Figure 6). A reduction in moisture can be seen with depth for the $\mathrm{RC}_{35}$ management, while $\mathrm{TC}_{5}$ maintained the moisture level throughout the profile. The greatest difference for soil moisture between the two managements was recorded in the 40 - 60 $\mathrm{cm}$ layer, which differed statistically $(p \leq 0.05)$. For the $0-20 \mathrm{~cm}$ level, the $\mathrm{TC}_{5}$ 
Fine roots $\left(\mathrm{Mg} \mathrm{ha}^{-1}\right)$

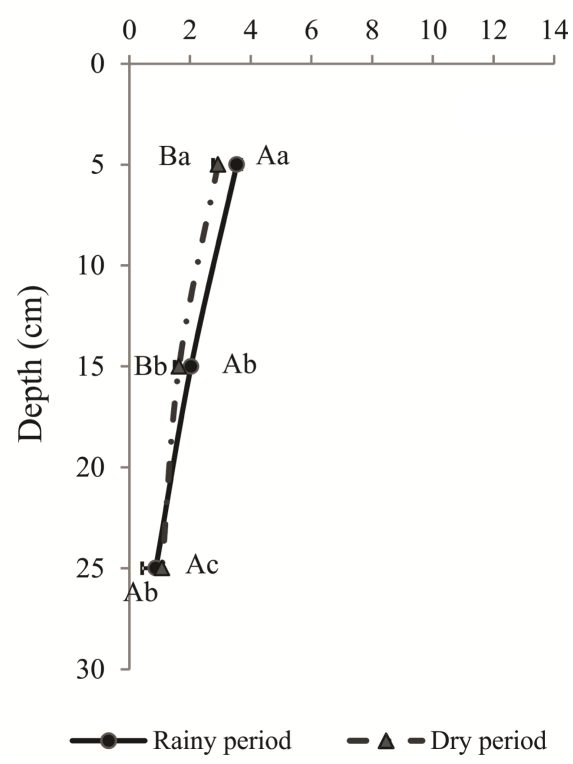

(a)
Fine roots $\left(\mathrm{Mg} \mathrm{ha}^{-1}\right)$

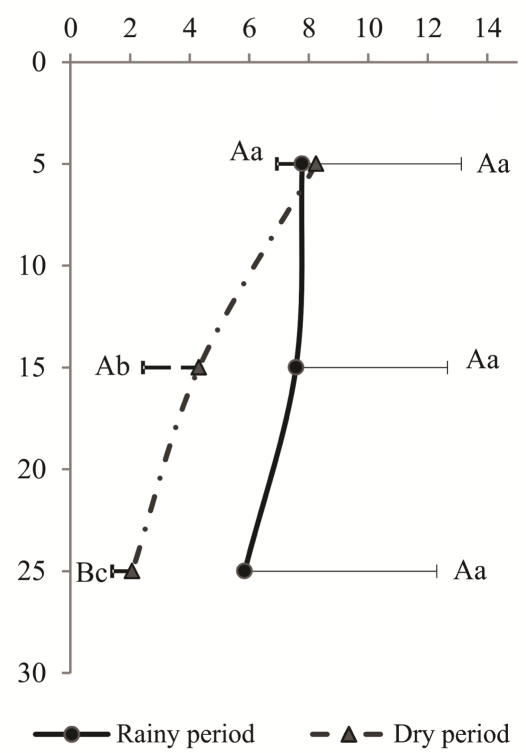

(b)

Figure 5. Dry fine-root biomass $\left(\mathrm{Mg} \cdot \mathrm{ha}^{-1}\right)$ present in the soil depth profile of the $\mathrm{RC}_{35}$ (a) $(\mathrm{n}=30)$ and $\mathrm{TC}_{5}(\mathrm{~b})(\mathrm{n}=30)$ managements. The same lowercase letters within a depth, and uppercase letters between periods (wet, dry), do not differ statistically by t-test ( $p>$ $0.05)$.

Soil moisture content (\%)

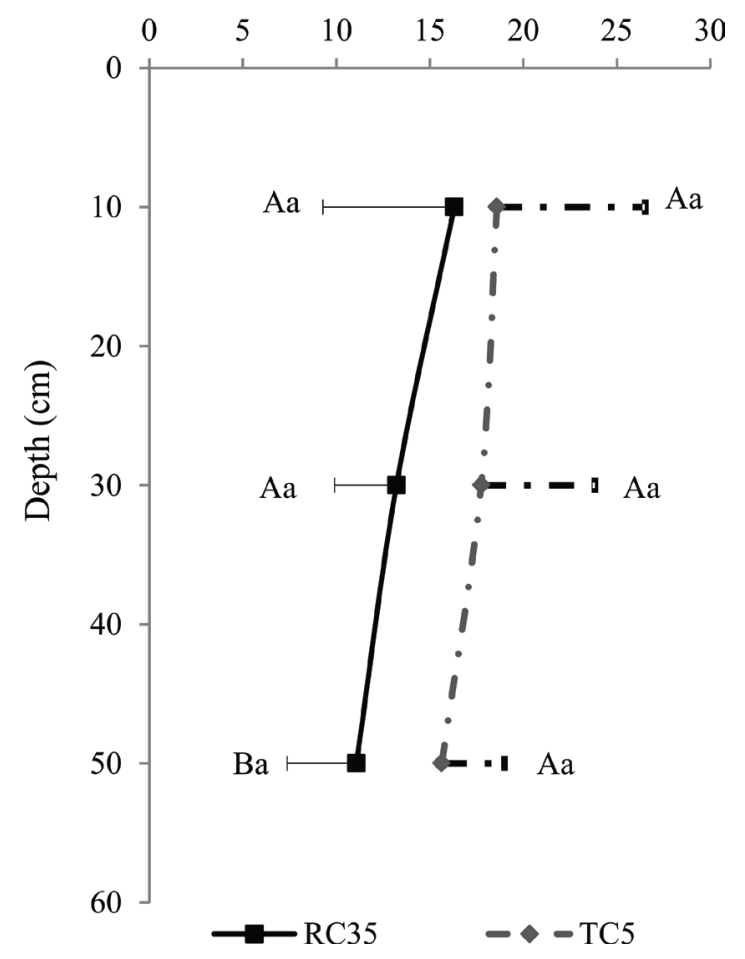

Figure 6. Mean moisture content of the soil profile. The same lowercase letters within a depth, and uppercase letters between managements do not differ statistically by t-test ( $p>$ $0.05)$. 
management displayed a mean moisture content of about $18 \%$, which did not differ statistically $(p>0.05)$ from the $\mathrm{RC}_{35}(16 \%)$. The greatest values for temporal variability were recorded in the surface layer $(0-20 \mathrm{~cm})$, with deviations of $8 \%$ in $\mathrm{TC}_{5}$ and $7 \%$ in $\mathrm{RC}_{35}$ (Figure 6 ).

\subsection{Total Soil Carbon and Total Nitrogen}

The stock of Total Soil Carbon (TSC) and Total Nitrogen (TN) in both managements (Figure $7(\mathrm{a})$ and Figure $7(\mathrm{~b}))$ showed no significant difference $(p>$ 0.05 ) in the $0-20 \mathrm{~cm}$ soil layer. However, for the remaining layers, the $\mathrm{TC}_{5} \mathrm{ex}-$ ceeded RC35 with respect to the stocks of TSC and TN $(p \leq 0.05)$. Moreover, it is important to note that the thinned vegetation is able to maintain a homogeneous stock of carbon throughout the soil depth profile, with values of $36.4 \mathrm{Mg} \cdot \mathrm{ha}^{-1}(0$ - $20 \mathrm{~cm}$ ), $29.9 \mathrm{Mg} \cdot \mathrm{ha}^{-1}(20-40 \mathrm{~cm})$ and $29.2 \mathrm{Mg} \cdot \mathrm{ha}^{-1}(40-60 \mathrm{~cm})$ (Figure $7(\mathrm{a}))$. In the surface layer $(0-20 \mathrm{~cm})$, the value for TSC in the $\mathrm{RC}_{35}$ was on average $30.2 \mathrm{Mg} \cdot \mathrm{ha}^{-1}$, being significantly $(p \leq 0.05)$ higher than in the other layers (Figure $7(\mathrm{a})$ ).

\subsection{Carbon Isotopes $\left(\delta^{13} \mathrm{C}\right)$}

In relation to the source of carbon in both managements, the values for $\delta^{13} \mathrm{C}$ were predominant in $\mathrm{TC}_{5}(p=0.01)$, ranging from $-22.6 \%$ o to $-18.5 \%$ o for the 0

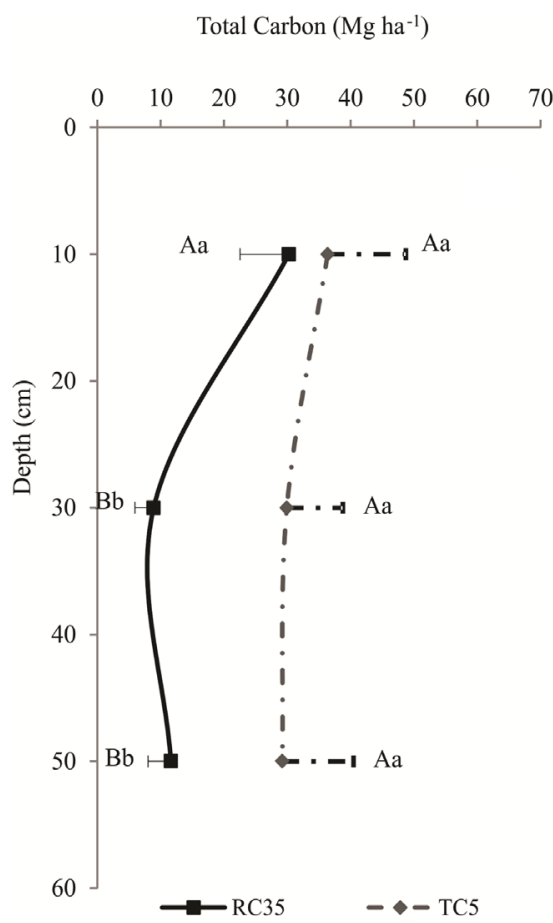

(a)
Total Nitrogen $\left(\mathrm{Mg} \mathrm{ha}^{-1}\right)$

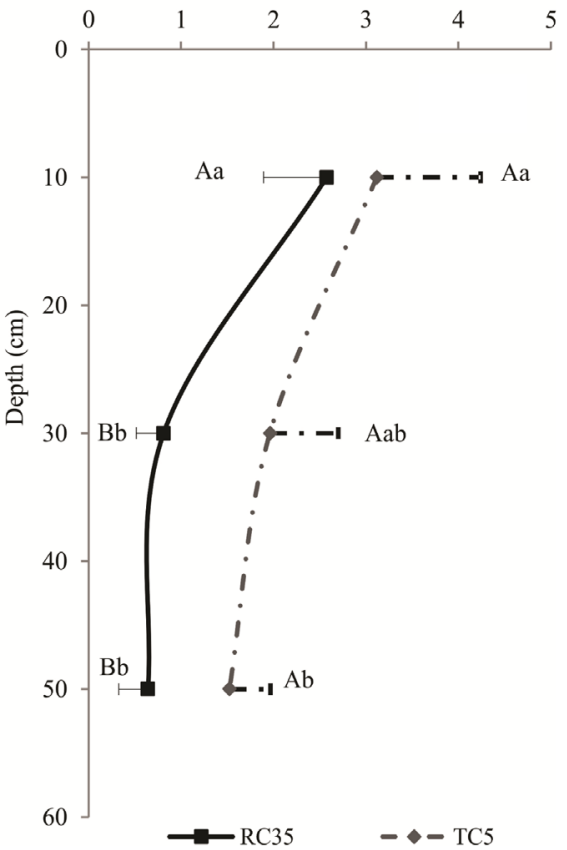

(b)

Figure 7. Stocks of TSC (a) and TN (b) in the soil profile of the $\mathrm{RC}_{35}(\mathrm{n}=105)$ and $\mathrm{TC}_{5}$ (105) managements from April 2013 to March 2014. The same lowercase letters within a depth, and uppercase letters between watersheds $\left(\mathrm{RC}_{35}, \mathrm{TC}_{5}\right)$ did not differ statistically by t-test $(p>0.05)$. 
- 20 and $40-60 \mathrm{~cm}$ layers respectively (Figure 8). Further, the smallest variations in the values of $\delta^{13} \mathrm{C}$ occurred in the $0-20 \mathrm{~cm}$ layer of the $\mathrm{RC}_{35}$ manage ment. Moreover, in this layer, the predominance of carbon, input from species with a $\mathrm{C}_{3}$ metabolic cycle, should be noted, i.e. arising from the residue of woody species. It can further be seen that the $\mathrm{TC}_{5}$ management showed greater heterogeneity in $\delta^{13} \mathrm{C}$ values, and that in the deepest layer $(40-60 \mathrm{~cm})$ there are significant increases in carbon from $\mathrm{C}_{4}$ species (tropical grasses), thereby differing statistically from the $\mathrm{RC}_{35}(p=0.015)$.

\section{Discussion}

\subsection{Herbaceous Biomass}

In the $\mathrm{RC}_{35}$, herbaceous biomass was little influenced by annual rainfall variability (Figure 3 and Figure 4). However, when the natural ground cover conditions were altered by the technique of thinning, significant differences in the production of dry biomass between the rainy and dry seasons became possible. As the vegetative stages in the phenological cycle of the species are short [4], within just two months from the end of the rains there is a significant reduction in the stock of dry matter in the vegetation, especially in the $\mathrm{TC}_{5}$. However, the occurrence of even small rainfall depths $(66 \mathrm{~mm})$ recorded during October and November, promoted the recovery of the net primary production in December (Figure 2 and Figure 3). This recovery is more significant in the $\mathrm{TC}_{5}$, differing statistically from $\mathrm{RC}_{35}$ due to the greater abundance of herbaceous species, a result of thinning.

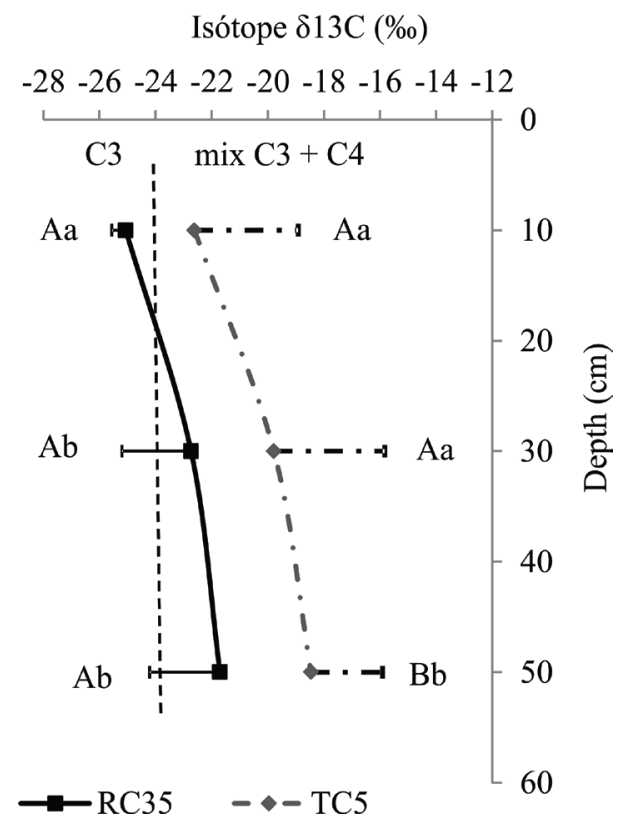

Figure 8. Contribution of $\mathrm{C}_{3}$ and $\mathrm{C}_{4}$ plants to stocks of $\mathrm{C}$ in the soil profile of the $\mathrm{RC}_{35}$ (n $=30)$ and $\mathrm{TC}_{5}(\mathrm{n}=30)$ managements. The same lowercase letters within a depth, and uppercase letters between managements $\left(\mathrm{RC}_{35}, \mathrm{TC}_{5}\right)$, do not differ statistically by t-test $(p>0.05)$. 
The greater availability of biomass in thinned area can be verified at the end of the rainy season, with high variability in the stock of dry biomass. A difference of more than $500 \%$ can occur between successive seasons [11]. The reduction in herbaceous dry matter in the $\mathrm{TC}_{5}$ area during the dry season is a result of the dormancy and/or senescence of the individuals (Figure 3 and Figure 4), promoted by a reduction in soil moisture. The surface layer expressed the greatest temporal variability for moisture (Figure 6), this being due to the flow of moisture exchange between the soil and the atmosphere by the process of evaporation as presented by [16].

The mean availability of dry biomass from the herbaceous vegetation in a SDTF ranges from 1.5 to $4.0 \mathrm{Mg} \cdot \mathrm{ha}^{-1}$ [5] [11]. Such variations are conditioned by local characteristics, especially ground cover by woody plants, and the time of evaluation [6] [18]. In SDTF, the technique of thinning transfers the production of biomass from the shrubs and trees to the herbaceous layer by an increase in grass and herbaceous dicot species [13].

According to the conceptual model of the main factors that control density in herbaceous species, proposed by [12], the factor of light penetration to the soil surface is more important than the fertility of the habitat itself. Therefore, greater availability in the flow of solar energy to be used in the photosynthetic process of the herbaceous layer located below the canopy of a forest subjected to thinning, contributes to an increase in biomass and fine roots, and consequently to the levels of organic matter in the soil.

\subsection{Fine Root Biomass}

The studies have shown that the concentration of fine roots throughout the soil profile in the $\mathrm{TC}_{5}$ only differed statistically between the rainy and dry seasons in the $20-30 \mathrm{~cm}$ layer. This is explained by the heterogeneous distribution of roots throughout the profile during the dry season (Figure 5(b)). For the same management, the largest stock of fine roots during the dry season was concentrated in the $0-10 \mathrm{~cm}$ layer, with approximately $8.3 \mathrm{Mg} \cdot \mathrm{ha}^{-1}$. This increased concentration in the surface layer is due to a shortening of the roots by the death of the apical zone [4] [21], or by a water deficit in the SDTF during the dry season. However, during the rainy period there was greater homogeneity in the concentration of fine roots along the vertical depth, with no significant difference $(p>$ $0.05)$ (Figure 5(b)). Although each type of vegetation has a different root architecture, use of the root to shoot ratio has been widely used to estimate the quantity of root biomass for the purposes of carbon accounting [20]. To this effect, several researchers have defended the use of allometric equations to estimate root and shoot biomass [6] [23] [34].

Therefore, it is expected with this study to find a greater correlation between the shoot biomass of herbaceous plants with the stock of fine roots. A higher root to shoot ratio in pasture, compared with forests or other woody vegetation, was found by [23]. Given the above, it can be inferred that the decrease in her- 
baceous shoot dry matter in the $\mathrm{TC}_{5}$ during the dry months of August to November (Figure 3 and Figure 4), a result of low rainfall and of the consequent reduction in soil moisture, is contributing to the death and subsequent reduction of fine-root biomass throughout the soil profile, which was not evident in the 20 - $30 \mathrm{~cm}$ layer of $\mathrm{TC}_{5}$ or the $0-10 \mathrm{~cm}$ layer of $\mathrm{TC}_{5}$ (Figure 5(a) and Figure 5(b)), respectively.

Therefore, after the end of the rainy period, there is a significant increase in organic residue in the soil from the death and rupturing of the fine roots of grasses and herbaceous legumes. The vegetation returns nutrients to the soil through the circulation of matter [34], represented by the deposition of litter and death of the roots, especially the fine roots. The greater distribution of fine roots in the soil profile with a predominance of herbaceous grasses makes possible the increase and release, by root exudation or decomposition, of soluble compounds, which are easily decomposable and usable as an energy source by microorganisms [25].

\subsection{Total Soil Carbon and Total Nitrogen}

The stock of carbon in the roots of SDTF forests around the world varies between 17 and $31 \mathrm{Mg} \cdot \mathrm{ha}^{-1}$ [5] [24] [35], values below those found in tropical rainforests (36 to $68 \mathrm{Mg} \cdot \mathrm{ha}^{-1}$ ) [36]. In the SDTF of northeastern Brazil, one of the few works developed in this biome on fine roots biomass found average values of $2.4 \mathrm{Mg} \cdot \mathrm{ha}^{-1} \cdot \mathrm{year}^{-1}$ [37]. This is an intermediate value to those found in the $\mathrm{RC}_{35}\left(3.3 \mathrm{Mg} \cdot \mathrm{ha}^{-1}\right.$ and $\left.1.7 \mathrm{Mg} \cdot \mathrm{ha}^{-1}\right)$, but well below those found in $\mathrm{TC}_{5}(21.2$ $\mathrm{Mg} \cdot \mathrm{ha}^{-1}$ and $14.6 \mathrm{Mg} \cdot \mathrm{ha}^{-1}$ ), for the rainy and dry seasons respectively.

Net amounts of TSC and TN in the $0-20 \mathrm{~cm}$ layer, regardless of ground cover, showed the highest temporal variability when compared to the other two layers, there being no statistical difference between the managements under study in the surface layer (Figure 7). The greater stocks of carbon seen in the $10-20 \mathrm{~cm}$ and $20-30 \mathrm{~cm}$ layers of soil in the $\mathrm{TC}_{5}$ compared to $\mathrm{RC}_{35}$ (Figure $7(\mathrm{a})$ ), are a result of the accumulation of organic residue mainly input after the death of the fine roots (Figure 5). Fine roots are the major suppliers of carbon to the soil when they die and decompose in large quantities during the dry season [4]. Carbon input to the soil is mainly due to the products of fine-root decomposition [6] to the illuviation of organic compounds from the decomposition of plant residues deposited on the soil [1], and to material incorporated by the movement of the macro and mesofauna [18].

Another factor that may have contributed to maintaining greater levels of carbon in the subsurface layers of the $\mathrm{TC}_{5}$ is based on the fact that herbaceous vegetation reduced surface runoff and increased the chances of infiltration [17]. The greater infiltration opportunity time in the $\mathrm{TC}_{5}$ management [15] contributed to an increase in moisture throughout the depth profile (Figure 6), and to growth of the root system of the herbaceous plants [10], as well as contributing with higher rates of carbon and nitrogen illuviation at greater depths in relation 
to $\mathrm{RC}_{35}$.

The concentrations of TSC in $\mathrm{RC}_{35}$ and of TN in both managements decreased with depth (Figure 6(a) and Figure 7(b)). It is known that the greater stocks of these elements at the soil surface, show an imminent risk of large amounts of $\mathrm{CO}_{2}$ being released from the soil surface to the atmosphere if land use is changed to managements of intense mobilisation and turning of the soil [38]. A greater accumulation of TSC and TN in the surface layer of the soil has been identified in different parts of the world [3] [5] [6] [39] [40] [41]. Carbon stocks in the 0 $20 \mathrm{~cm}$ layer of $\mathrm{RC}_{35}\left(30 \mathrm{Mg} \cdot \mathrm{ha}^{-1}\right)$ and $\mathrm{TC}_{5}\left(40 \mathrm{Mg} \cdot \mathrm{ha}^{-1}\right)$ are within the range of values found in soils of the Brazilian semi-arid region, from 20 to $48.4 \mathrm{Mg}^{-h^{-1}}$ [27]; of the Amazon region, at a depth of $30 \mathrm{~cm}$, of 30 to $60 \mathrm{Mg} \cdot \mathrm{ha}^{-1}$ [26] and of the Brazilian Cerrado, $38.7 \mathrm{Mg} \cdot \mathrm{ha}^{-1}$ [22].

\subsection{Carbon Isotopes $\left(\delta^{13} \mathrm{C}\right)$}

The source of the carbon present in each management (Figure 8) confirms observations made in the field regarding the use and occupation of the area being investigated. The significant enrichment of $\delta^{13} \mathrm{C}$ with depth in the soil under the $\mathrm{RC}_{35}$ management shows that the site has been under different types of land use in the past. The local community reports that 35 years earlier, both areas had been historically intended for the cultivation of maize. The most likely hypothesis therefore is that the carbon at subsurface depths $(20-40$ and $40-60 \mathrm{~cm})$ in $\mathrm{RC}_{35}$ is a remnant of old humidified organic matter from previous vegetation which was richer in $\delta^{13} \mathrm{C}$ than today. Similar behaviour was found by [42] in studies on reforestation with leguminous trees. Managements of monocropped corn, regardless of soil type, contributed with higher values for $\delta^{13} \mathrm{C}$ throughout the profile [41], where the values for $\delta^{13} \mathrm{C}$ range from $-9 \%$ to $-19 \%$, with a mean of $-13 \%$ [ [43].

The slight enrichment of $\delta^{13} \mathrm{C}$ values at greater depths in $\mathrm{RC}_{35}$ (Figure 8) may even be associated with the decomposition of organic substrates, which would involve a normal isotopic effect, i.e. microbial products become more enriched in $\delta^{3} \mathrm{C}$ than do substrates [44]. Another possible cause of this variability lies in the fact that with humidification, the values for $\delta^{13} \mathrm{C}$ tend to increase over time [42].

Changes in ground cover due to the practice of thinning, and the consequent increase in the population of tropical grasses, contributed to an increase in organic waste from plant species with $\mathrm{C}_{4}$ metabolic cycle, at lower depths (40 - 60 $\mathrm{cm}$ ) of $\mathrm{TC}_{5}$ area (Figure 8). Therefore, the hypothesis of the recent increase in carbon from organic waste being input to the soil organic matter in the thinned area by the death and rupturing of the fine roots of grasses is proven, as shown in Figure 5(b). Researchers such as [40] found mean values for $\delta^{13} \mathrm{C}$ equal to $-27 \%$ in areas of forest under regeneration, being within the range $(-22 \%$ o to $-34 \%$ ) corresponding to $\mathrm{C}_{3}$ plants [45]; whereas in areas of pasture, the values found are higher (a mean of $-22 \%$ ), close to those found in the present study, indicating enrichment of $\delta^{13} \mathrm{C}$ from the organic material of the grasses. 
However, unlike $\mathrm{RC}_{35}$, in addition to the old source, the area subjected to thinning shows a significant increase in more recent sources of $\delta^{13} \mathrm{C}$ at lower depths (Figure 8). This result is consistent with studies by [46], who found that the introduction of brachiaria grass (Brachiaria decumbens), a plant with $\mathrm{C}_{4}$ metabolism, in managed pasture which replaced a forested area of cerrado, altered the isotopic signature of the soil carbon to less negative values, between $-15.26 \%$ and $-17.58 \%$.

\section{Conclusion}

This work points to the implementation of thinning in a SDTF emerging as a management alternative to be considered in sustainability programs in the semi-arid region, contributing to maximizing the production of herbaceous forage for feeding large and small ruminants, and for bee pasture, in addition to increasing the stock of carbon in the soil of SDTF and can help to reduce global warming The management of thinning $\left(\mathrm{TC}_{5}\right)$ contributes to greater stocks of TSC and total NT in the soil of a sazonally dry tropical forest, when compared to the reference area (area under regeneration for 35 years). Stocks of herbaceous dry biomass in the area under $\mathrm{TC}_{5}$ were greater during the rainy season. Under $\mathrm{RC}_{35}$ management, stocks remain constant regardless of the time of year. The increase in herbaceous cover influenced soil moisture dynamics, the increased humidity allowing fine roots to penetrate to a greater depth. This favoured an increase in carbon throughout the soil profile, originating from the organic residue of vegetable species with a $\mathrm{C}_{4}$ metabolic cycle (tropical grasses). Despite having smaller amounts of shoot biomass, values for the stocks of carbon and nitrogen in the soil found in this study are close to those seen in other Brazilian biomes, such as the Cerrado and the Amazon Rainforest.

\section{Acknowledgements}

The authors wish to thank Brazilian National Council for Scientific and Technological Development $(\mathrm{CNPq})$ and Coordination for the Improvement of Higher Education Personnel (CAPES) for their financial support of this research.

\section{References}

[1] Garcia-Gonzalo, J., Peltola, H., Briceno-Elizondo, E. and Kellomaki, S. (2007) Changed Thinning Regimes May Increase Carbon Stock under Climate Change: A Case Study from a Finnish Boreal Forest. Climatic Change, 81, 431-454. https://doi.org/10.1007/s10584-006-9149-8

[2] Ferry, B., Morneau, F., Bontemps, J.D., Blanc, L. and Freycon, V. (2010) Higher Treefall Rates on Slopes and Waterlogged Soils Result in Lower Stand Biomass and Productivity in a Tropical Rain Forest. Journal of Ecology, 98, 106-116. https://doi.org/10.1111/j.1365-2745.2009.01604.x

[3] Ma, W., et al. (2016) Soil Erosion, Organic Carbon and Nitrogen Dynamics in Planted Forests: A Case Study in a Hilly Catchment of Hunan Province China. Soil 
and Tillage Research, 155, 69-77.

[4] Asaye, Z. and Zewdie, S. (2013) Fine Root Dynamics and Soil Carbon Accretion under Thinned and Un-Thinned Cupressus lusitanica Stands in, Southern Ethiopia. Plant and Soil, 366, 261-271. https://doi.org/10.1007/s11104-012-1420-3

[5] Pereira Júnior, L.R., Andrade, E.M., Palácio, H.A.Q., Raymer, P.C.L., Ribeiro Filho, J.C. and Pereira, F.J.S. (2016) Carbon Stocks in a Tropical Dry Forest in Brazil. Revista Ciência Agronômica, 47, 32-40. https://doi.org/10.5935/1806-6690.20160004

[6] Vargas, R., Allen, E.B. and Allen, M.F. (2009) Effects of Vegetation Thinning on Above- and Below-Ground Carbon in a Seasonally Dry Tropical Forest in Mexico. Biotropica, 41, 302-311. https://doi.org/10.1111/j.1744-7429.2009.00494.x

[7] Miles, L.A.C., et al. (2006) A Global Overview of the Conservation Status of Tropical Dry Forests. Journal of Biogeography, 33, 491-505. https://doi.org/10.1111/j.1365-2699.2005.01424.x

[8] Breceda, A., Ortiz, V. and Scrosati, R. (2005) Mauto (Lysiloma divaricatum, Fabaceae) Allometry as Ana Indicator of Cattle Grazin Pressure in a Dry Tropical Forest in Northwestern Mexico. Rangeland Ecology \& Management, 58, 85-88. https://doi.org/10.2111/1551-5028(2005)58<85:MLDFAA >2.0.CO;2

[9] Guo, Q.F. (1998) Microhabitat Differentiation in Chihuahuan Desert Plant Communities. Plant Ecology, 139, 71-80. http://www.jstor.org/stable/20050696 https://doi.org/10.1023/A:1009737025870

[10] Savadogo, P., Tiveau, D., Sawadogo, L. and Tigabu, M. (2008) Herbaceous Species Responses to Long Term Effects of Prescribe Fire, Grazing and Selective Cutting Tree in the Savanna-Woodland of West Africa. Perspectives in Plant Ecology, Evolution and Systematics, 10, 179-195.

[11] Araújo Filho, J.A., Carvalho, F.C., Garcia, R. and Sousa, R.A. (2002) Effects of the Manipulation Methods of Woody Vegetation on Production and Compartimentalization of the Grazeable Phytomass of a Successional Caatinga. Revista Brasileira de Zootecnia, 31, 11-19. https://doi.org/10.1590/S1516-35982002000100002

[12] Grace, J.B. (1999) The Factors Controlling Species Density in Herbaceous Plant Communities: An Assessment. Perspectives in Plant Ecology, Evolution and Systematics, 1, 1-28. https://doi.org/10.1078/1433-8319-00063

[13] Schacht, W.H., Long, J.M. and Malechek, J.C. (1988) Above-Ground Production in Cleared and Thinned Stands of Semiarid Tropical Woodland, Brazil. Forest Ecology and Management, 23, 201-214.

[14] Kirmse, R.D., Provenza, F.D. and Malechek, J.C. (1988) Coppice Management in Brazilian Semiarid Tropics: Effects on Forage Production and Quality for Small Ruminants. Agroforestry Systems, 5, 429-441. https://doi.org/10.1007/BF00047177

[15] Andrade, E.M., Guerreiro, M.J.S. and Rodrigues, J.O. (2016) Change in Hydrological Response of Catchments in a Dry Tropical Forest Subject to Land Use Changes. 9th Spanish Portuguese Assembly of Geodesy and Geophysics, Madrid.

[16] Jia, Y.H. and Shao, M.A. (2014) Dynamics of Deep Soil Moisture in Response to Vegetational Restoration on the Loess Plateau of China. Journal of Hydrology, 519, 523-531.

[17] Rodrigues, J.O., Andrade, E.M., Mendonça, L.A.R., Araújo, J.C., Palácio, H.A.Q. and Araújo, E.M. (2013) Hydrological Responses in Small Watersheds in the Semiarid Region According to Land Use. Revista Brasileira de Engenharia Agrícola e Ambiental, 17, 312-318. https://doi.org/10.1590/S1415-43662013000300010

[18] Alvear, M., Astorga, M. and Reyes, F. (2008) Effects of Vegetal Residues from Two 
Sylvicultural Treatments in Pinus radiata D. Don Plantation on Seasonal Changes of the Biological Activities of Soil. Journal of Soil Science and Plant Nutrition, 8, 1427. https://www.researchgate.net/publication/286837403

[19] Smolander, A., Kitunen, V., Kukkola, M. and Tamminen, P. (2013) Response of Soil Organic Layer Characteristics to Logging Residues in Three Scots Pine Thinning Stands. Soil Biology and Biochemistry, 66, 51-59.

[20] Albuquerque, E.R.G.M., Sampaio, E.V.S.B., Pareyn, F.G.C. and Araújo, E.L. (2015) Root Biomass under Stem Bases and at Different Distances from Trees. Journal of Arid Environments, 116, 82-88.

[21] Pinheiro, E.A.R., Costa, C.A.G. and Araújo, J.C. (2013) Effective Root Depth of the Tropical Dry Forest Biome. Journal of Arid Environments, 89, 1-4.

[22] Maia, S., Ogle, S. and Cerri, C. (2009) Effect of Grassland Management on Soil Carbon Sequestration in Rondônia and Mato Grosso States, Brazil. Geoderma, 149, 84-91.

[23] Mokany, K.R., Raison, R.J. and Prokushkin, A.S. (2006) Critical Analysis of Root: Shoot Ratios in Terrestrial Biomes. Global Change Biology, 12, 84-96. https://doi.org/10.1111/j.1365-2486.2005.001043.x

[24] Jaramillo, V., Boone, J., Rodriguez, R.L., Cummings, D. and Ellingson, L. (2003) Biomass, Carbon, End Nitrogen Pools in Mexican Tropical Dry Forest Landscapes. Ecosystems, 6, 609-629. https://doi.org/10.1007/s10021-002-0195-4

[25] Kuzyakov, Y. and Domanski, G. (2000) Carbon Input by Plants into the Soil. Review. Journal of Plant Nutrition and Soil Science, 163, 421-431. https://doi.org/10.1002/1522-2624(200008)163:4<421::AID-JPLN421>3.0.CO;2-R

[26] Bernoux, M., Carvalho, M.C.S., Volkoff, B. and Cerri, C.C. (2002) Brazil's Soil Carbon Stocks. Soil Science Society of America Journal, 66, 888-896. https://doi.org/10.2136/sssaj2002.8880

[27] Giongo, V., Galvão, S.R.S., Mendes, A.M.S., Gava, C.A.T. and Cunha, T.J.F. (2011) Soil Organic Carbon in the Brazilian Semi-Arid Tropics. Dynamic Soil, Dynamic Plant, 5, 12-20. http://www.alice.cnptia.embrapa.br/bitstream/doc/915039/1/Vanderlise2011.pdf

[28] USDA, Natural Resource Conservation Service (1999) Sampling Vegetation Attributes. $164 \mathrm{p}$.

[29] Andrade, A.R.S., Paixão, F.J.R., Azevedo, C.A.V., Gouveia, J.P.G. and Oliveira Júnior, J.A.S. (2009) Study of the Behavior of Dry and Rainy Periods in the City of Garanhuns, PE, with Agricultural Planning as a Goal. Pesquisa Aplicada \& Agrotecnologia, 1, 55-61.

http://revistas.unicentro.br/index.php/repaa/article/viewFile/6/5

[30] Park, B.B. and Yanai, R.D. (2007) Estimating Root Biomass in Rocky Soils Using Pits, Cores, and Allometric Equations. Soil Science Society of America Journal, 71, 206-213. https://doi.org/10.2136/sssaj2005.0329

[31] Veldkamp, E. (1994) Organic Carbon Turnover in Three Tropical Soils under Pasture after Deforestation. Soil Science Society of America Journal, 58,175-180. https://doi.org/10.2136/sssaj1994.03615995005800010025x

[32] Blake, G.R. and Hartge, K.H. (1986) Bulk Density. In: Klute, A., Ed., Methods of Soil Analysis. Physical and Mineralogical Methods, 2nd Edition, ASA-SSSA, Madison, 363-375.

[33] Hoefs, J. (2004) Stable Isotope in Geochemistry. 5th Edition, Springer Verlag, Berlin, 244 p. https://doi.org/10.1007/978-3-662-05406-2 
[34] Vogt, K.A., Vogt, D.J. and Bloomfield, J. (1998) Analysis of Some Direct and Indirect Methods for Estimating Root Biomass and Production of Forests at an Ecosystem Level. Plant and Soil, 200, 71-89. https://doi.org/10.1023/A:1004313515294

[35] Raherison, S.M. and Grouzis, D.M. (2005) Plant Biomass, Nutrient Concentration and Nutrient Storage in a Tropical Dry Forest in the South-West of Madagascar. Plant Ecology, 180, 33-45. https://doi.org/10.1007/s11258-005-8063-X

[36] Sarmiento, G., Pinillos, M. and Garay, I. (2005) Biomass Variability in Tropical American Lowland Rainforests. Ecotropicos, 18, 1-20. http://www.saber.ula.ve/handle/123456789/25579

[37] Salcedo, I.H. and Sampaio, E.V.S.B. (2008) Soil Organic Matter in the Biome Caatinga. Fundamentals Soil Organic Matter: Tropical and Subtropical Ecosystems. 2nd Edition, Porto Alegre, 419-441.

[38] Tiessen, H., Feller, C., Sampaio, E.V.S.B. and Garin, P. (1998) Carbon Sequestration and Turnover in Semiarid Savannas and Dry Forests. Climatic Change, 40, 105-117. https://doi.org/10.1023/A:1005342932178

[39] Aticho, A. (2013) Evaluating Organic Carbon Storage Capacity of Forest Soil: Case Study in Kafa Zone Bita District, Southwestern Ethiopia. American-Eurasian Journal of Agricultural \& Environmental, 13, 95-100.

[40] Costa, O.V., Cantarutti, R.B., Fontes, L.E.F., Costa, L.M., Nacif, P.G.S. and Faria, J.C. (2009) Soil Carbon Stocks under Pasture in Costal Tableland Areas in Southern Bahia State, Brazil. Revista Brasileira de Ciência do Solo, 33, 1137-1145. https://doi.org/10.1590/S0100-06832009000500007

[41] Fuentes, M., Govaerts, B., Hidalgo, C., Etchevers, J., González-Martín, I., Hernández-Hierro, J.M., Sayre, K.D. and Dendooven, L. (2010) Organic Carbon and Stable 13C Isotope in Conservation Agriculture and Conventional Systems. Soil Biology and Biochemistry, 42, 551-557.

[42] Torres, A.Q.A. (2011) Dynamics of Soil Organic Matter in Degraded Area under Recovery by Planting Leguminous Trees in Angra dos Reis, RJ. Master Science in Agronomy, Soil Science. Federal University Rural of Rio de Janeiro, $42 \mathrm{p}$.

[43] Cerri, C.C. and Volkoff, F. (1991) Nature and Behaviour of Organic Matter in Soils under Natural Forest, and after Deforestation, Burning and Cultivation, near Manaus. Forest Ecology and Management, 38, 247-257.

[44] Balesdent, J., Mariotti, A. and Guillet, B. (1987) Natural 13C Abundance as a Tracer for Studies of Soil Organic Matter Dynamics. Soil Biology and Biochemistry, 19, 25 30.

[45] Veldkamp, E. (1993) Soil Organic Carbon Dynamics in Pastures Established after Deforestation in the Humid Tropics of Costa Rica. Tese, Van de Landbouwuniversiteit.

[46] Rosolen, V., Resende, T.M., Borges, E.M., Frare, C.T. and Machado, H.A. (2012) Impacts of Conversion of the Original Brazilian Cerrado Vegetation in Agriculture Systems: Changes of Soil Organic Carbon and $\delta^{13} \mathrm{C}$. Investigaciones Geográficas, Boletín del Instituto de Geografía, UNAM, 79, 39-47.

http://www.scielo.org.mx/pdf/igeo/n79/n79a4.pdf 
Submit or recommend next manuscript to SCIRP and we will provide best service for you:

Accepting pre-submission inquiries through Email, Facebook, LinkedIn, Twitter, etc. A wide selection of journals (inclusive of 9 subjects, more than 200 journals)

Providing 24-hour high-quality service

User-friendly online submission system

Fair and swift peer-review system

Efficient typesetting and proofreading procedure

Display of the result of downloads and visits, as well as the number of cited articles Maximum dissemination of your research work

Submit your manuscript at: http://papersubmission.scirp.org/

Or contact ajps@scirp.org 